\title{
Market Knowledge and Dynamic Capabilities in Creating Competitive Advantage in an International New Venture
}

\author{
Anders Pehrsson \\ Linnaeus University \\ Anders.Pehrsson@lnu.se \\ Minna Rollins \\ University of West Georgia \\ mrollins@westga.edu
}

\begin{abstract}
This paper focuses on market knowledge and dynamic capabilities in creating competitive advantage in a local unit of an International New Venture (INV). This paper draws on the knowledgebased view of the firm and builds a conceptual model that illustrates the impact of broad and deep market knowledge on the local unit's competitive advantage and performance. It is proposed that the INV unit needs dynamic capabilities in order to efficiently convert market knowledge into competitive advantage and then performance. Managerial implications, next steps of the research, and avenues for the future research are discussed.
\end{abstract}

Keywords: Knowledge Management, market knowledge, dynamic capabilities, International New Ventures

\section{Introduction}

Due to efficient communication technologies, setting up an International New Venture (INV) has become increasingly relevant and easy when there is a need for an international establishment in a new location [10, 21, 42]. An INV refers to firm that is international from its inception [6]. There is a need to further understand competitive advantage of a local unit of the INV that operates in different markets with varying degrees of dynamism. "A local unit" refers to for example a subsidiary or a sales unit of INV.

The local unit may encounter exogenous barriers to compete due to liabilities of foreignness [31, 33]. Without a strong competitive advantage that distinguishes the offerings of the unit of the INV from offerings of competitors [44], it is difficult for the INV to perform well in the local market. Competitive advantage of the local unit adds to the overall performance of the INV.

Drawing on the knowledge-based view of the firm, the purpose of this paper is to extend the understanding the role of market knowledge creating competitive advantage of a local unit of an INV. The focus is the role of market knowledge because broad and deep knowledge [11] regarding competitors and customers that is crucial in developing competitive advantages [40, 46, 50, 52]. Market knowledge is manifested by knowhow [24] relevant to, for example, the identification of preferences of customers and barriers to competition. Further, a local unit needs extensive dynamic capabilities, capabilities that efficiently aligns resources and routines with environmental changes [51, 53], in order to efficiently convert the knowledge into competitive advantage.

The following sections of the paper present the theoretical foundation, the conceptual model and propositions regarding relationships among the components of the model. Paper concludes with the discussion of managerial implications and future research avenues and next steps of this research.

\section{Theoretical foundation}

\subsection{Knowledge-based view of the firm}

The knowledge-based view of the firm emphasizes the strategic importance of leveraging knowledge to support and enhance firm performance. The firm is viewed as a knowledge stock that may be explicit or originate from experiences [18, 30, 35].

Grant [18] states that the knowledge-based view of the firm provides a theoretical base for explaining 
situations where knowledge needs to be transferred across the firms' boundaries, in this case from one INV unit to another.

Nonaka et al. [23] go further by explaining that firms exists for the purpose of creating and applying knowledge. Organization's ability to create and apply knowledge yields a competitive advantage [23]. INV and its units gain competitive advantage by possessing and utilizing market knowledge. In addition, the knowledge-based view stipulates that a dynamic learning capability is decisive to firm's competitive advantages [29].

\subsection{Market Knowledge in International Markets}

The stock of knowledge in the organization can be described along two dimensions [11]: 1) knowledge breadth and 2) knowledge depth. First, broad market knowledge concerning competitors and customers is accumulated anywhere in the INV; it is relevant to more than one unit. Broad market knowledge concerns markets in any market. As international competitors and customers frequently operate in more than one market knowledge accumulated about them can be relevant to several local units. Broad market knowledge can be and should be transferred and shared with other local units [1, 4, 19, 26].

Each local unit accumulates deep market knowledge from its own local market. This includes in knowledge of the behavior of important local competitors or barriers that a local unit encounters when conducting business in a particular market segment [41, 45]. Barriers include in issues such as loyalties with other suppliers and/or costs that a potential customer may encounter if switching to another supplier [7].

\subsection{Competitive advantage of a local unit}

A competitive advantage is the principal foundation of performance of the INV's local unit. Sales growth is a relevant manifestation of performance as such growth would be a common objective of the INV as a whole. By emphasizing a decisive competitive advantage that differentiates the offerings of the unit of the INV from offerings of competitors [44], the local unit would be able to break through barriers to access customers. The advantage would also balance any negative effects due to liabilities of foreignness $[31,33]$.

Essentially, a competitive advantage builds on low prices or potential customer benefits beyond low prices [44]. In the former case, the INV needs to restrict costs in all organizational units consistently. However, in order to bring success, low prices require larger sales volumes, and hence, that an enough customers who prioritize low prices in relation to other value drivers.

An emphasis beyond low prices may rest on product or customer characteristics [38]. Regarding product advantages, an advantage of a local unit may build on efficient product innovativeness that drive the market. Depending on customer characteristics, values may also rely on efforts to customize products in order to fulfill customer requirements [38].

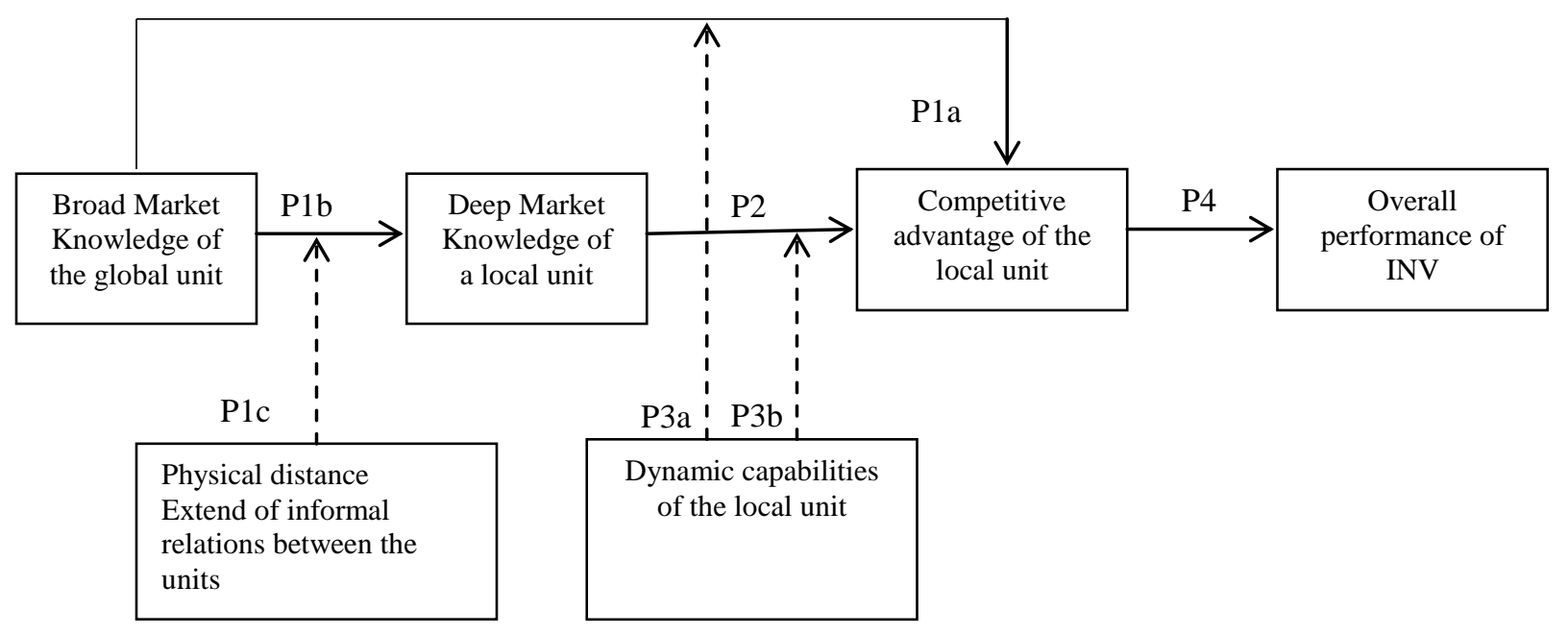

Figure 1 Conceptual model 


\section{The Conceptual Model}

Figure 1 presents the conceptual model that illustrates how broad and deep market knowledge contribute competitive advantage of the local unit of INV. The extend of dynamic capabilities of the local unit play important role in this relationship; the unit is able to assimilate the incoming market knowledge only if it possesses enough dynamic capabilities.

\subsection{Broad market knowledge}

Buckley and Ghauri [8], Luo [28], Oh and Contractor [36], and Pehrsson [40] propose that a firm's corporate strategy is an important source of broad market knowledge. Therefore, continued international expansion means that the firm is constantly exposed to a broader range of competitors and customers, and the firm accumulates a greater amount of broad market knowledge over time.

The knowledge-based view stipulates that it is less costly to use and share existing market knowledge than to create new knowledge [18]. Therefore, the INV as a whole benefits from transferring and sharing broad market knowledge to its local units.

P1a: Broad market knowledge contributes positively on competitive advantage of an international new venture's local unit.

The local unit need to be able to assimilate the incoming broad market knowledge with deep market knowledge and use it when meeting local competitors and serving local customers. I order to compete, the local unit may exploit market knowledge that has been important in other markets. Use of existing knowledge in forming the local competitive advantage, thus, limits risks and uncertainty as it represents best practice of the firm. The local unit could become more competitive, if the INV is able to transfer and share a broad range of knowledge of competitors and customers. In addition, access to a common stock of market knowledge may motivate management in local units to exploit corporate-wide advantages [13]. Therefore, we propose as follows:

P1b: Broad market knowledge of the global unit contributes positively to deep market knowledge of an INV local unit.

In accordance with the knowledge-based view [18], specialization makes knowledge creation efficient. Therefore, it is important to shed light on what facilitates transfer and sharing of broad market knowledge and specialized replication of market knowledge.

Transferring and sharing of broad market knowledge is facilitated through the organization structure [16] and short physical distance [54]. In addition, relatedness among products and markets of the transferring unit and the local unit [5, 42] as well as relations among individual managers, facilitate the transfer and the local unit's efforts to build a specialized advantage [34].

Product and markets may be related along key dimensions such as a product's physical features and characteristics of sales channels [37]. Extensive relatedness essentially means standardization and a risk of obstruction of the local unit's efforts to develop a specialized competitive advantage that suits the local market.

Informal relations among involved managers facilitate the local unit's use of broad market knowledge in order to create a specialized competitive advantage in each market. Such relations are work-based relationships among individuals that facilitate interpersonal discussions, and, thus, the knowledge transfer. Informal relations are characterized by norms, habits, and personal reciprocity [20]. In particular, informal relations that are stable over time favor the transfer of market knowledge from one manager to another [20, 34]. This leads us to propose as follows:

P1c: Short physical and cultural distance and close informal relations between units strengthen the relationship between broad and deep market knowledge.

\subsection{Deep market knowledge}

The local unit acquires and generates deep knowledge of competitors and customers in its own market. Analyses of available information regarding the product/market range constitute a major foundation of the knowledge creation [42]. The range is an indicator of deep market knowledge as a broader range is generally associated with greater exposure to market changes. Thus, a local unit is able to efficiently analyze market information and build deep market knowledge gets valuable inputs into the development of its competitive advantage.

Market knowledge about the overall industry structure and local competitors are particularly crucial when it comes to developing competitive advantage $[14,32,44]$. Such knowledge are 
necessary in order to identify and evaluate exogenous barriers.

In principle, exogenous barriers such as obstacles to access customers are structural parts of the market [48]. Exogenous barriers include in issues such as customers' switching costs, loyalties among buyers and sellers, sales channel availability, and scale effects such as a need for low costs. For example, a strong relationship between a customer and another supplier means that the customer may be less interested in turning to the focal unit of the INV if a switch implies any costs. Through the unit's accumulation of market knowledge such as knowledge of exogenous barriers the competitive advantage will be strengthened.

It is central that the local unit generates deep market knowledge. The local unit would then extend its capability of, for example, approaching a range of customers, identifying target groups and sales channels, and responding to competition [23, 52]. This leads us to propose as follows:

P2: Deep market knowledge of a local unit of INV contributes positively to competitive advantage of an international new venture's local unit.

\subsection{The Role of Dynamic Capabilities}

The dynamic capabilities theory has emerged from the resource-based theory [18, 43]. Here, a firm's resources are considered to be the most stable ground for competitive advantage. Essentially, a dynamic capability is decisive to a firm's exploitation of its resources. The theory predicts that a firm needs dynamically to use its capability to integrate, build and reconfigure knowledge to efficiently respond to changes in the environment [12, 25, 49, 51, 53].

The dynamic capabilities theory is particularly useful when explaining firms' performance where firms mainly compete on intangible assets, for example, in global and knowledge-based service economies. Dynamics in the competitive environment commonly differs from one local unit of the INV to another. This means that it is crucial for a particular unit to possess enough capabilities to be able to convert market knowledge into competitive advantages that fit the local market. Hence, if the dynamic capabilities of the local unit are efficient they would reinforce the positive impact of market knowledge on the competitive advantage of the unit.

The environment of the local unit can be dynamic for instance due to extensive price competition. In this case, the majority of competitors emphasize low prices and, as a result, there is great rivalry. If the local unit of the INV wishes to compete on prices as well, it needs to reduce costs extensively. As an alternative, it has to adjust its competitive advantage. This would require relevant knowledge of competitors' behaviour and preferences of customers, and internal reconfiguration of the unit's resources. For example, emphasis on product and service quality instead of low prices means that the salesforce needs to be educated in order to be able to inform customers of quality aspects of products and services. Hence, extensive dynamic capabilities of the salesforce reinforce the competitive advantage of the local unit.

If competitors generally rely on customer benefits other than low prices, there is more complexity as customers requirements may vary from benefits preferred by just one customer to those that are preferred by many customers. The latter setting is, thus, particularly complex and heterogeneous and the unit needs fine-tuned knowledge of the market. More precisely, the local unit needs to recognize several factors originating from customers' needs [9]. In addition, the unit needs to re-configurate the resources accordingly relying on its dynamic capabilities. Extend and variety of local unit's range of dynamic capabilities is expected to reinforce the positive effects of both broad and deep market knowledge on competitive advantage. We also propose the relationship between competitive advantage and performance.

P3a: The comprehensive dynamic
capabilities, the stronger the positive effect
of broad market knowledge on the
competitive advantage of an international
new venture's local unit.

P3b: The comprehensive dynamic capabilities, the stronger the positive effect of deep market knowledge on the competitive advantage of an international new venture's local unit.

P4: Competitive advantage leads to better overall performance of the INV.

\section{Conclusions}

This paper builds on the knowledge-based view and proposes the conceptual model that focuses on broad and deep market knowledge and the moderating effect of dynamic capabilities. The INV local unit that is able to break through exogenous barriers to competition demonstrates a strong 
competitive advantage in comparison to those of competitors and contributes to the INV's overall performance.

The model proposes that broad and deep knowledge of market, i.e. competitors and customers, strengthen the competitive advantage of a local unit. In addition, model proposes that a local unit that possesses extensive capabilities to adapt to dynamic market changes is able to align its resources and routines with the changes, i.e. dynamic capabilities reinforce the unit's competitive advantage.

The conceptual model contributes to current literature three ways. First, the model contributes to literature on international new ventures as it clarifies the impact of market knowledge on competitive advantage. Despite the relevance of establishing INVs and a common desire to achieve quick financial results, previous studies show conflicting results regarding the relationship between internationalization and performance $[2,3,15,22$, 27]. In order to extend the understanding of the complex relationship between an INV's competitive advantage and performance, this paper shows that research needs to look for the role of dynamic capabilities.

Second, the model contributes by demonstrating that the knowledge-based view is relevant to the understanding of an INV's competitive advantage. The relationship between two types of market knowledge, broad and deep are discussed.

Third, application of theory on dynamic capabilities is relevant to the understanding of the issue. The local unit can create competitive advantage only if it possess extensive and broad dynamic capabilities that allow for use of both broad and deep market knowledge.

\subsection{Managerial implications}

Management of an INV is advised to carefully evaluate potential drivers for competitive advantage. First, it is important to realize that the competitive situation frequently differs from one market to the other and, it is difficult to find one universal advantage that suits all local markets. Second, the local unit needs support from the global unit in its efforts to assimilate broad market knowledge stemming from other parts of the INV and adapting knowledge to the local competitive situation. Third, there is a need for support of efforts to build local and specialized knowledge of competitors and customers that strengthen the local competitive advantage.

\subsection{Future Research}

This paper built the conceptual model that could be tested empirically as well as enhanced with interviewing personnel of INVs. The future research could especially explore the relationship and dynamics between broad and deep market knowledge. For instance, how deep market knowledge gained from one market can enhance the broad market knowledge or how deep market knowledge is collected and shared among units. Qualitative study could suggest best practices for collecting and sharing market knowledge between the units.

Statistical tests of the model enhanced with qualitative interviews could follow. Data from INVs practices of collecting and sharing of both broad and deep market knowledge could be collected with cross-sectional survey. Data for performance measures could be collected from secondary sources as well as from the INVs itself.

\section{References}

[1] F. Achcaoucaou, P. Miravitlles, and F. LeónDarder, "Knowledge sharing and subsidiary R\&D mandate development: a matter of dual embeddedness", International Business Review, 2014, Vol. 23, pp. 76-90.

[2] P. Almodóvar and A.M. Rugman, "The M curve and the performance of Spanish international new ventures", British Journal of Management, 2014, Vol. 25 No. 1, pp. 6-23.

[3] E. Autio, H.J. Sapienza, and J.G. Almeida JG, "Effects of age at entry, knowledge intensity, and imitability on international growth", Academy of Management Journal, 2000, Vol. 43, pp. 909-924.

[4] N. Åkerman, "Knowledge-acquisition strategies and the effects on market knowledge: profiling the internationalizing firm", European Management Journal, 2015, Vol. 33 No. 2, pp. 79-88.

[5] J. Barney, Gaining and Sustaining Competitive Advantages, Addison-Wesley, Reading, MA, 1997.

[6] M. Baum, C. Schwens, R. Kabst, "A typology of international new ventures: empirical evidence from high-technology industries", Journal of Small 
Business Management, 2011, Vol. 49 No. 3, pp. $305-$ 330

[7] T.H. Brusk, R. Dangol, and J.P. O'Brien, "Customer capabilities, switching costs, and bank performance", Strategic Management Journal, 2012, Vol. 33 No. 13, pp. 1499-1515.

[8] P.J. Buckley and P.N. Ghauri, "Globalization, economic geography, and the strategy of MNEs", Journal of International Business Studies, 2004, Vol. 35 No. 2, pp. 81-98.

[9] B. Clarysse, J. Bruneel, and M. Wright, "Explaining growth paths of young technology-based firms: structuring resource portfolios in different competitive environments", Strategic Entrepreneurship Journal, 2011, Vol. 5, pp. 137-157.

[10] N.E. Coviello, McDougall PP, and Oviatt BM, "The emergence, advance and future of international entrepreneurship research: an introduction to the special forum", Journal of Business Venturing, 2011, Vol. 26 No. 6, pp. 625-631

[11] L.M. DeLuca and K. Atuahene-Gima, "Market knowledge dimensions and cross-functional collaboration: examining the different routes to product innovation performance", Journal of Marketing, 2007, Vol. 71 No. 1, pp. 95-112.

[12] K. Eisenhardt and J. Martin, "Dynamic capabilities: what are they? Strategic Management Journal, 2000, Vol. 21 No. 10/11, pp. 1105-1121.

[13] Y. Fang, M. Wade, A. Delios, and P.W. Beamish, "International diversification, subsidiary performance, and the mobility of knowledge resources", Strategic Management Journal, 2007, Vol. 28 No. 10, pp. 1053-1064.

[14] E. Fang and S. Zou, "Antecedents and consequences of marketing dynamic capabilities in international joint ventures", Journal of International Business Studies, 2009, Vol. 40 No. 5, pp. 742-761.

[15] S.A. Fernhaber, "Untangling the relationship between new venture internationalization and performance", Journal of International Entrepreneurship, 2013, Vol. 11, pp. 220-242.

[16] J.R. Galbraith, Designing Complex Organizations, Addison-Wesley, Reading, MA, 1976.
[17] R. Grant, "The resource-based theory of competitive advantage: implications for strategy formulations", California Management Review, 1991, Vol. 33 No. 3, pp. 114-135.

[18] R.M. Grant, "The knowledge-based view of the firm", in Choo, C.W. and Bontis, N. (Eds), The Strategic Management of Intellectual Capital and Organizational Knowledge, Oxford University Press, Oxford, pp. 133-148, 2002.

[19] A.K. Gupta and V. Govindarajan, "Knowledge flows within multinational corporations", Strategic Management Journal, 2000, Vol. 21 No. 4, pp. 473496.

[20] M. Hansen and B. Lövås, "How do multinational companies leverage technological competencies? Moving from single to interdependent explanations", Strategic Management Journal, 2004, Vol. 25 No. 8/9, pp. 801-822

[21] M.V. Jones, N. Coviello, and Y.K. Tang, "International entrepreneurship research (19892009): a domain ontology and thematic analysis", Journal of Business Venturing, 2011, Vol. 26, pp. 632-659.

[22] S. Khavul, L. Pérez-Nordtvedt, and E. Wood "Organizational entrainment and international new ventures from emerging markets", Journal of Business Venturing, 2010, Vol. 25 No. 1, pp. 104119.

[23] D.J. Ketchen, C.C. Snow, and V.L. Hoover, Hoover, "Research on competitive dynamics: recent accomplishments and future challenges", Journal of Management, 2004, Vol. 30 No. 6, pp. 779-804.

[24] B. Kogut and U. Zander, "Knowledge of the firm, combinative capabilities, and the replication of technology", Organization Science, 1992, Vol. 3, pp. 383-397.

[25] A. Kuuluvainen, "How to concretize dynamic capabilities? Theory and examples", Journal of Strategy and Management, 2012, Vol. 5 No. 4, pp. 381-392.

[26] R.P. Lee, Q. Chen, D. Kim, and J.L. Johnson, "Knowledge transfer between multinational corporations' headquarters and their subsidiaries: influences on and implications for new product outcomes", Journal of International Marketing, 2008, Vol. 16, No. 2, pp. 1-31. 
[27] J.W. Lu and P.W. Beamish, "The internationalization and performance of SMEs", Strategic Management Journal, 2001, Vol. 22 No. 6/7, pp. 565-586.

[28] Y. Luo, "Dynamic capabilities in international expansion," Journal of World Business, 2000, Vol. 35

No. 4, pp. 355-78.

[29] X. Martin and R. Salomon, "Tacitness, learning, and international expansion: a study of foreign direct investment in a knowledge-intensive industry", Organization Science, 2003, Vol. 14, No. 3, pp. 297 311.

[30] X. Martin and R. Salomon, "Knowledge transfer capacity and its implications for them theory of multinational corporation", Journal of International Business Studies, 2003, Vol. 38, No. 4, pp. 356-373.

[31] J. Mata and P. Portugal, "The survival of new domestic and foreign-owned firms", Strategic Management Journal, 2002, Vol. 4, pp. 323-343.

[32] K. Matsuno and J. Mentzer, "The effects of strategy type on the market orientation-performance relationship", Journal of Marketing, 2000, Vol. 64, pp. 1-16

[33] J.M. Mezias, "Identifying liabilities of foreignness and strategies to minimize their effects: the case of labor lawsuit judgments in the United States", Strategic Management Journal, 2002, Vol. 23, No. 3, pp. 229-244.

[34] N. Nohria and S. Ghoshal, The Differentiated Network: Organizing Multinational Corporations for Value Creation, Jossey-Bass, San Francisco, CA, 1997.

[35] I. Nonaka, "A dynamic theory of organizational knowledge creation", Organization Science, 1994, Vol. 5, No. 1, pp. 14-37.

[36] C. H. Oh and F.J. Contractor, "The role of territorial coverage and product diversification in the multinationality-performance relationship", Global Strategy Journal, 2012, Vol. 2 No. 2, pp. 122-36.

[37] A. Pehrsson, "Business relatedness and performance: a study of managerial perceptions", Strategic Management Journal, 2006, Vol. 27 No. 3, pp. 265-82.
[38] A. Pehrsson, “Firms' customer responsiveness and performance: the moderating roles of dyadic competition and firm's age", Journal of Business \& Industrial Marketing, 2014, Vol. 29, No. 1, pp. 3444.

[39] A. Pehrsson, “Firm's strategic orientation, market context, and performance: literature and opportunities for international strategy research", European Business Review, 2016, Vol. 28, No. 4, pp. 378-404.

[40] A. Pehrsson, 'Sequential foreign expansion in a foreign market: knowledge drivers and contingencies of establishments of additional subsidiaries', European Business Review, 2016, Vol. 28, No. 3, pp. 285-311.

[41] A. Pehrsson and T. Pehrsson, "Competition barriers and foreign subsidiary growth: propositions on the contextual role of strategic orientation", International Journal of Business Competition and Growth, 2015, Vol. 4, No. 1/2, pp. 3-23.

[42] T. Pehrsson, N. Ghannad, A. Pehrsson, T. Abt, S. Chen, F. Erath, and T. Hammarstig, "Dynamic capabilities and performance in foreign markets: developments within international new ventures", Journal of International Entrepreneurship, 2015, Vol. 13, No.1, pp. 28-48.

[43] E. Penrose: The Theory of the Growth of the Firm. Blackwell, Oxford, UK, 1959.

[44] M.E. Porter: Competitive Strategy, The Free Press, New York, NY, 1980.

[45] M.E. Porter, Competitive Advantage: Creating and Sustaining Superior Performance, The Free Press, New York, NY, 1985.

[46] S. Prashantham, "Toward a knowledge-based conceptualization of internationalization", Journal of International Entrepreneurship, 2005, Vol. 3, 37-52.

[47] R.P. Rumelt, "Diversification strategy and profitability", Strategic Management Journal, 1982, Vol.

3 No. 4, pp. 359-69.

[48] W. Shepherd, The Economics of Industrial Organization, Prentice-Hall, Englewood Cliffs, NJ, 1979. 
[49] D. Teece, G. Pisano, and A. Shuen, "Dynamic capabilities and strategic management", Strategic Management Journal, 1997, Vol. 47, pp. 509-533

[50] A. Tuppura, S. Saarenketo, K. Puumalainen, A. Jantunen, and K. Kyläheiko, "Linking knowledge, entry timing and internationalization strategy", International Business Review, 2008, Vol. 17, pp. 473-487.

[51] W.P. Wan, R.E. Hoskisson, J.C. Short, and D.W. Yiu, "Resource-based theory and corporate diversification: accomplishments and opportunities", Journal of Management, 2011, Vol. 37 No. 5, pp. 1335-1368.

[52] P.L. Yeoh, "International learning: antecedents and performance implications among newly internationalizing companies in an exporting context", International Marketing Review, 2004, Vol. 21, No 4/5, pp. 511-535.

[53] S.A. Zahra, H.J. Sapienza, and P. Davidsson, "Entrepreneurship and dynamic capabilities: a review, model and research agenda", Journal of Management Studies, 2006, Vol. 43 No. 4, pp. 917955.

[54] S. Zaheer, "Overcoming the liability of foreignness", Academy of Management Journal, 1995, Vol. 38, pp. 341-364. 